Boletim Científico do Instituto Agronômico do Estado de S. Paulo

Vol. 31

Campinas, janeiro de 1972

N. ${ }^{\circ} 6$

\title{
MICROSCOPIA ELECTRONNICA DE MICRORGANISMOS DO TIPO MICOPLASMA NOS TECIDOS DE MILHO AFETADO PELO ENFEZAMENTO E NOS ÓRGÃOS DA CIGARRINHA VECTORA PORTADORA $\left.{ }^{1}\right)$
}

\author{
E. W. Kita jima e A. S. Costa $\left({ }^{2}\right)$, engenheiros-agrônomos, Seção \\ de Virologia Fitotécnica, Instituto Agronômico
}

\section{SINOPSE}

Exames electrono-microscópicos de tecido foliar ou radicular de milho (Zea mays L.) afetado pelo enfezamento do milho, tanto a forma vermelha como a pálida, e de órgãos da cigarrinha vectora, Dalbulus maidis De L. \& W., portadora, demonstraram a ocorrência de corpúsculos pleomórficos, do tipo micoplasma, consistentemente associados a essa anomalia. Não se notou diferença na morfologia entre os microrganismos do tipo micoplasma associados às duas formas do enfezamento da planta nem tampouco entre estes e os presentes no inseto vector. Verificou-se também que na planta esses corpúsculos do tipo micoplasma ocorriam somente nos vasos crivados, e que no inseto eles se achavam presentes em diversos tipos de tecidos de diferentes órgãos - tubo digestivo, músculo, túbulos de Malphigi, epiderme, gânglio nervoso, glândula salivar, tecido adiposo. Nas células do inseto, os corpúsculos ocorriam dispersos no citoplasma ou em cavidades limitadas por membrana.

\section{1 - INTRODUÇÃO}

O enfezamento ("stunt") do milho (Zea mays L.) é uma moléstia de comum ocorrência no Estado de São Paulo. Sua incidência, contudo, é inexpressiva na época normal do cultivo do milho, sendo apenas importante nos plantios de inverno, quando pode dar prejuízos sérios, fato este que deve estar ligado ao movimento da população da cigarrinha vectora Dalbulus maidis De L. \& W. Além disso, no Estado de São Paulo, foram reconhecidas

( ${ }^{1}$ ) Este trabalho recebeu auxílios financeiros da FAPESP (C. Agron. 69/879). CNPq (TC 12275) e do convênio CAPES/BID/BNDE. Recebido para publicação em 20 de agosto de 1971.

${ }^{2}$ ) Com bolsa de suplementação do CNPq. 
duas formas de enfezamento: a pálida, correspondente ao chamado tipo Rio Grande, dos EUA, que se caracteriza pela redução no porte, grandes áreas foliares desprovidas de clorofila, e a forma vermelha, equivalente ao tipo Mesa Central, do México, que induz um amarelecimento nas bordas e das extremidades das folhas, seguida de um avermelhamento (3). O enfezamento do milho foi tido por muito tempo, desde sua primeira descrição (1), como tendo etiologia virosa (11). Contudo, recentes estudos nos EUA $(2,6,7)$ e no Brasil $(9)$ demonstraram que essa anomalia está associada a microrganismos do tipo micoplasma.

Este trabalho relata resultados de um estudo electrono-microscópico dessa moléstia, em que se procurou analisar comparativamente o agente das duas formas de enfezamento, nos tecidos da planta e da cigarrinha vectora.

\section{2 - MATERIAL E METODOS}

Plantas de milho-pipoca foram inoculadas por cigarrinhas vectoras portadoras (colonizadas sobre plantas com enfezamento), da forma vermelha ou pálida do enfezamento, em condições de estufa.

Amostras de folha e raiz, dessas plantas, foram colhidas cerca de 60 dias após a inoculação, quando elas exibiam sintomas típicos, e fixadas com glutaraldeído a $3 \%$ em tampão fosfato $0,05 \mathrm{M}, \mathrm{pH}$ 7,2 , durante 2 horas a $4^{\circ} \mathrm{C}$. Após lavagem em solução tampão, o tecido foi pós-fixado em $\mathrm{OsO}_{4}$ a $1 \%$ em tampão fosfato $0,15 \mathrm{M}$ durante 1 hora. A cigarrinha foi fixada da mesma maneira, e para facilitar a penetração do fixador, usualmente se separava o abdômen da cabeça e tórax. O material fixado foi desidratado em acetona e incluído em Epon. Seções ultra-finas foram obtidas com um ultramicrótomo Porter-Blum MT-1, dotado de navalha de diamante, e coradas com acetato de uranila e citrato de chumbo, antes de serem examinadas ao microscópio Elmiskop I.

Como controle, amostras de plantas sadias, não inoculadas, e de cigarrinhas criadas em plantas sadias, foram processadas de maneira similar e examinadas. 


\section{3 - RESULTADOS}

a) Tecidos de milho afetado pelo enfezamento.

Nos tecidos, foliar ou radicular, de milho com sintomas de enfezamento, tanto da forma pálida como da vermelha, verificou-se a constante presença de corpúsculos de forma e dimensões variadas no interior dos vasos crivados (estampas 1 e 2). Em geral, tais corpúsculos apresentavam-se com perfil circular ou elíptico, mas alguns deles tinham contorno irregular ou apresentavam-se bastante alongados. Suas dimensões variavam de ca. $0,1 \mu \mathrm{m}\left({ }^{3}\right)$ até ca. $0,7 \mu \mathrm{m}$. Seções favoráveis demonstravam que os corpúsculos achavam-se limitados por uma membrana unitária, exibindo a típica estrutura trilamelar, de ca. $10 \mathrm{~nm}$ de espessura, a qual achava-se desprovida de qualquer proteção externa. Em seu interior ocorriam granulações do tipo ribosoma, de ca. $15 \mathrm{~nm}$ de diâmetro, usualmente distribuídas na periferia, enquanto na região central notava-se um reticulado de material filamentoso, semelhante às fibrilas de DNA em mitocôndrio e plastídio. Os corpúsculos, de pequenas dimensões, em geral apareciam mais densos, e neles raramente podiam-se distinguir as fibrilas do tipo DNA. Em seções favoráveis, junto ao crivo da placa crivada dos vasos liberianos, corpúsculos passando através do poro, aproveitando a sua plasticidade, puderam ser vistos (estampa 2-B).

Além dos corpúsculos, os vasos crivados usualmente continham componentes normais, dentre os quais o mais conspícuo era um material alongado de 25-30 nm de diâmetro, com estrutura helicoidal. Sua natureza não se acha esclarecida, mas provavelmente representa uma substância similar à proteína $\mathrm{P}(\mathbf{5})$, uma vez que a sua forma típica, fibrilar ou tubular, não pôde ser notada nos vasos crivados do milho.

Embora no caso do "stunt" do milho, norte-americano, corpúsculos pleomórficos houvessem sido detectados no parênquima adjacente aos vasos crivados (6), no presente estudo não se fez constatação análoga.

$$
\left.c^{3}\right) \mu \mathrm{m}=\text { micrômetro }=10^{-6} \mathrm{~m} ; \mathrm{nm}=\text { namômetro }=10^{-9} \mathrm{~m} \text {. Système Internacio. }
$$
nale d'Unités (SI). Nature 216:1272, 1967. 
Não se verificou nenhuma diferença sensível na morfologia dos corpúsculos encontrados em tecidos de plantas afetadas pela forma vermelha ou pálida do enfezamento. Por outro lado, esses corpúsculos nunca puderam ser detectados nos vasos crivados ou outros tecidos de plantas sadias, não inoculadas.

b) Tecidos da cigarrinha vectora.

Corpúsculos similares aos de milho afetado pelo enfezamento, nos vasos crivados foram também encontrados, em grande número, no interior de cigarrinhas Dalbulus maidis criadas em plantas afetadas pelo enfezamento, forma pálida ou vermelha (estampas 3-5), capazes de transmitir o patógeno. Ao contrário da planta afetada, onde os corpúsculos ocorriam somente nos vasos crivados, na cigarrinha vectora eles puderam ser notados numa grande variedade de órgãos e tecidos. Assim, foram esses corpúsculos detectados na luz (estampa 4-A) e no epitélio intestinal (estampas 3-A; 4-B), nas células periféricas do gânglio nervoso, nas células musculares (estampa 5-A), na glândula salivar (estampa 3-B), nas células epidérmicas (estampa 5-B), no tecido adiposo e túbulos de Malphigi. Em células reprodutivas, contudo, não puderam eles ser notados. Quanto à quantidade desses corpúsculos nos tecidos, notou-se que no epitélio intestinal usualmente era onde eles ocorriam em maior quantidade. Nos outros órgãos, se bem que às vezes ainda em quantidade apreciável, o número de corpúsculos era bem menor. Além disso, observou-se que, onde esses corpúsculos do tipo micoplasma ocorriam, eles apresentavam-se numa variedade de dimensões, desde as partículas menores de ca. $0,1 \mu \mathrm{m}$ até outras várias vezes maiores.

Nos tecidos onde ocorriam os corpúsculos do tipo micoplasma, foram eles observados dispersos no citoplasma, ou agrupados em cavidades limitadas por membranas.

Em cigarrinhas colonizadas sobre plantas sadias de milho, não se constatou a ocorrência desses corpúsculos pleomórficos, embora ocasionalmente fossem detectadas partículas que se assemelhavam a Ricketsia, como já anteriormente mencionado para outras cigarrinhas $(13,15)$. 


\section{4 - DISCUSSÃO}

Conforme já relatado preliminarmente (9), corpúsculos pleomórficos acham-se consistentemente associados ao enfezamento do milho, no Estado de São Paulo. Similar constatação já fora feita nos EUA, com o tipo Rio Grande do "com stunt" $(\mathbf{6}, \mathbf{7})$, o que vem confirmar o relacionamento, feito através de estudos patológicos, entre o enfezamento do milho do Estado de São Paulo e o "stunt" ou " achaparramiento" do milho norte e centro-americano (3). A morfologia desses corpúsculos se assemelha à de micoplasma (= PPLO), e é aceitável que o enfezamento do milho tenha assim etiologia micoplasmática, como tem sido sugerido para numerosas outras moléstias do grupo amarelo $(\mathbf{4}$, revisões em $\mathbf{9}, \mathbf{1 5})$. E interessante lembrar que no Estado de São Paulo já foram constatadas outras anomalias, como cálice gigante do tomateiro, superbrotamento da mandioca e de diversas plantas ornamentais, hortícolas e silvestres, também associadas a corpúsculos do tipo micoplasma (8-10). Não há, contudo, evidências de que o enfezamento do milho possa estar relacionado com alguma dessas moléstias.

As observaçōes feitas no presente estudo demonstraram que os corpúsculos do tipo micoplasma encontrados em tecidos de plantas afetadas pelo enfezamento ou de cigarrinhas vectoras portadoras, tanto da forma vermelha como da pálida, são indistinguíveis morfologicamente, o que corrobora as evidências patológicas de que essas duas formas seriam causadas por estirpes de um mesmo patógeno (3). Contudo, não se pode presentemente dar excessivo peso à morfologia para analisar semelhanças ou diferenças entre os diferentes microrganismos do tipo micoplasma, associados a diversas moléstias vegetais do grupo amarelo, pois, excetuando-se o caso do "greening" dos citros (12), em que se descreve uma ligeira variação na estrutura envoltória dos corpúsculos, em mais de 30 casos até agora estudados todas as descriçōes desses corpúsculos têm sido monotonamente similares.

Apesar de não existirem diferenças morfológicas entre os corpúsculos do tipo micoplasma, que ocorrem nos tecidos da planta afetada e do inseto vector, verificou-se no caso presente que, enquanto na planta os corpúsculos ocorrem apenas nos vasos criva- 
dos, na cigarrinha os corpúsculos aparecem em diversos tipos distintos de tecidos e órgãos. Fato similar já foi descrito no caso do "stunt" do milho norte-americano (6), da filódia do trevo (13) e do "western- $X$ " do pessegueiro (16). Isto sugere que na planta apenas os vasos liberianos podem oferecer os metabólitos necessários para a sobrevivência e multiplicação desses microrganismos, mesmo em hospedeiras adequadas. Por outro lado, no inseto vector, quase todas as células se prestariam para essa finalidade, conforme demonstra o exame histológico, em que se nota a ocorrência desses corpúsculos em grande variedade de órgãos e tecidos. E claro que a mera ocorrência de corpúsculos em determinado tecido não implicaria na sua multiplicação. Mas a existência de partículas de diferentes tamanhos e em partes da célula de acesso aparentemente mais difícil são sugestivas de que os numerosos corpúsculos aí presentes resultaram de uma multiplicação e não de um simples acúmulo.

Esse tipo de relacionamento com o organismo no qual se acha presente indicaria que os corpúsculos do tipo micoplasma se acham mais bem adaptados ao inseto do que à planta. Em outras palavras, esses corpúsculos pleomórficos representariam parasitas ou simbiontes que acidentalmente passaram a infetar o milho. Contudo, desde que esses microrganismos não são transmitidos transovarianamente, o milho representa presentemente um elo importante em seu ciclo evolutivo. Mas não fica eliminada a possibilidade de que, na falta do milho ou de outra planta, na qual esse microrganismo do tipo micoplasma se multiplique, cigarrinhas da espécie vectora de uma nova geração adquiram-no ao se alimentarem numa planta na qual o microrganismo não se multiplique, planta essa que possa funcionar como um reservatório temporário de corpúsculos injetados por outra cigarrinha portadora.

O grande número de corpúsculos presentes no epitélio intestinal da cigarrinha vectora parece corroborar a tese de Maillet e outros (14), de que aí se dá intensamente sua multiplicação e acúmulo, antes de se espalharem pelo resto do organismo do inseto, via hemolinfa. E interessante ressaltar que usualmente a glân- 
dula salivar não contém quantidade apreciável desses corpúsculos, e isso deve estar relacionado com a relativa ineficiência de Dalbulus maidis como vectora.

\section{ELECTRON MICROSCOPY OF MYCOPLASMA-LIKE ORGANISMS IN CORN STUNT - INFECTED PLANT TISSUES AND IN THE ORGANS OF THE LEAFHOPPER VECTOR}

\section{SUMMARY}

Corn stunt in São Paulo State is usually of minor importance during normal summer crops but might induce significant losses if corn is planted late in the season. It is transmitted by leaf-hopper Dalbulus maidis De $\mathrm{L}$. \& W. and two different forms of this disease have been recognized the chlorotic, similar to the Rio Grande type of the U.S.; and the red, resembling the Mesa Central type of Mexico.

Electron microscopic examination of tissues from both affected plants or leafhopper reared on diseased plants, demonstrated the presence of pleomorphic, mycoplasma-like bodies, consistently associated with the corn stunt, which probably represent the causal agent the latter. No significant difference could be observed in the morphology of these mycoplasma-like bodies associated with the two disease types or with the insect vector. In the affected plants, these corpuscles were only found in the sieve tubes; in the insect body they were detected in several types of tissues of different organs - intestine, Malphigian tubules, muscle, nervous ganglion, salivary gland, fat body, epidermis. In the insect cells, the pleomorphic bodies occurred either scattered in the cytoplasm or in cytoplasmic cavities boun. ded by membrane.

\section{LITERATURA CITADA}

1. ALSTATT, G. E. A new disease in the Rio Grande Valley. Pl. Dis. Reptr. 29:533-534, 1945.

2. CHEN, T. A. \& GRANADOS, R. R. Plant pathogenic mycoplasma-like organism: maintainance in vitro and transmission to Zea mays $\mathrm{L}$. Science 167:1633-1636, 1970.

3. COSTA, A. S.; KITAJIMA, E. W. \& ARRUdA, S. Moléstias de vírus e de micoplasma do milho no Est. S. Paulo Reunião Anual Soc. Bras. Fitopat., 4, Piracicaba, 1971.

4. DOI, Y.; TERANAKA, M., YORA, K. \& ASUYAMA, H. Mycoplasma-or PLT-group-like microorganisms found in the phloem elements of plants infected with mulberry dwarf, potato witches' broom, aster yellows, or paulownia witches' broom. Ann. phytopath. Soc. Japan 33:259-266, 1967.

5. ESAU, K. \& CRONSHAW, J. Tubular and fibrillar components of mature and differentiating sieve elements. J. Cell Biol. 34:801-815, 1967.

6. GRANADOS, R. R. Electron microscopy of plants and insect vectors infected with corn stunt disease agent. Contr. Boyce Thompson Inst. 24:173-188, 1969. 
7. GRANADOS, R. R.; MARAMOROSCH, K. \& SHIKATA, E. Mycoplasma suspected etiologic agent of corn stunt. Proc. natn. Acad. Sci. U.S.A. 60:841.844, 1968 .

8. KITAJIMA, E. W. \& COSTA, A. S. Estruturas do tipo micoplasma no floema de tomateiro afetado pelo cálice gigante. Bragantia 27:XCVII-XCIX, 1968. Nota 23.

9. $\&$ Micoplasma: possível agente etiológico de certas moléstias de plantas. Ciência e Cultura 22:351-363, 1970.

10. — \& Corpúsculos do tipo micoplasma associados a diversas moléstias de planta, no grupo amarelo, no Est. S. Paulo. Ciência e Cultura 23:285-291, 1971.

11. KUNKEL, L. L. Incubation period of corn stunt virus in the leafhopper Baldulus maidis (DeL. and W.). Am. J. Bot. 33:830-831, 1946.

12. LAFLECHE, D. \& BOVE, J. M. Structures de type mycoplasme dans les feuilles d'orangers atteints de la maladie du greening. C. $r$. Acad. Sci. (Paris) 270 (série D):1915-1917, 1970.

13. MAILLET, P. L. Infection simultanée 'par des particules de type PLT (Ricketsiales) et de type PPLO (Mycoplasmatales) chez un insect vecteur de la phyllodie du trèfle, Euscelis lineolatus Brullé (Homoptera, Jassidae) J. Microscopie 9:827-832, 1970.

14. - GOURRET, J. P. \& GOURANTON, J. Biologie et cytopathologie des particles de type mycoplasme dans la plante et l'insect vecteur. Proc. 7th Int. Conf. Electron Microscopy 3:355-356, 1970.

15. MARAMOROSCH, K.; SHIKATA, E. \& GRANADOS, R. R. Structures resembling mycoplasma in diseased plants and in insect vectors. Trans. N. Y. Acad. Sci. (série II) 30:841-855, 1968.

16. NASU, S.; JENSEN, D.D. \& RICHARDSON, J. Electron microscopy of mycoplasma-like bodies associated with insect and plant hosts of peach western-X disease. Virology 41:583-595, 1970. 